\title{
Stock Market Development, Financial Deepening and Economic Growth in Africa
}

\author{
Asiedu Michael*, Nana Adwoa Anokye Effah, Tchuiendem Nelly Joel, \\ Agyeiwaa Owusu Nkwantabisa
}

School of Accounting, Zhongnan University of Economics and Law, Wuhan, China

Email: ^masiedu256@gmail.com, Effahnanaadwoa@gmail.com,nellyjoel20@outlook.com, agyeiwaaowusu1844@gmail.com

How to cite this paper: Michael, A., Effah, N. A. A., Joel, T. N., \& Nkwantabisa, A. O. (2021). Stock Market Development, Financial Deepening and Economic Growth in Africa. Journal of Financial Risk Management, 10, 1-24.

https://doi.org/10.4236/jfrm.2021.101001

Received: November 11, 2020

Accepted: March 2, 2021

Published: March 5, 2021

Copyright $\odot 2021$ by author(s) and Scientific Research Publishing Inc. This work is licensed under the Creative Commons Attribution International License (CC BY 4.0).

http://creativecommons.org/licenses/by/4.0/

\begin{abstract}
In this study, we employed the dynamic autoregressive distributed lag bounds test, co-integration test and granger causality test to examine the long-run and short run interrelationship among financial deepening, stock market development and economic growth for eight (8) countries in Africa using annual data for the period 1996-2019 to establish the interrelationship between Africa's developing capital markets and the real side of their economies. While we found the series in five countries (Nigeria, Algeria, Namibia, Kenya and Mauritius) to be co-integrated; three other countries were not. The result from the granger causality test established bi-directional causality between economic growth (lnGDP) and stock market development (STMCAP/GDP) in Algeria, Namibia and Mauritius as the remaining five countries recorded only unidirectional causality from economic growth (lnGDP) to stock market development (STMCAP/GDP). Our panel analysis revealed a positive relationship between stock market development (STMCAP/GDP) and financial deepening (M2/GDP). There is a positive relationship between economic growth (lnGDP) and financial deepening (M2/GDP) for all the countries except for Eswatini and Mauritius. Further analysis of the interrelationship with economic growth (lnGDP) as dependent variable found significant and varying results for the time series across countries. However, the results from the panel regression found no significant effect from both financial deepening (M2/GDP) and stock market development (STMCAP/GDP) in Africa. To this end, we recommend swift and systematic reforms tailored towards improving the efficiency for their capital markets.
\end{abstract}

\section{Keywords}

Economic Growth, Stock Market Development, Financial Deepening 


\section{Introduction}

The roles of financial markets and the deepening of the financial systems are very crucial to the advancement of all modern societies. This is in line with modern growth theories highlighting the significance of stock markets and financial development in the pursuit of macroeconomic goals even though both the empirical and theoretical literature remains inconclusive and populated with mixed findings. More important is also the fact that; most of the empirical literature has centered on the most advanced economies of North America, Europe and some emerging economies in Asia due to the long history of their financial markets, robustness and the availability of data. The stock market performs several roles, including the breaking of bulky transactions, capital allocation and generally serves as an information channel for investors. In this paper we examine the interrelationship among financial development, stock market development and economic growth in eight (8) Africa countries (Nigeria, Algeria, Namibia, Kenya, Mauritius, Eswatini, South Africa and Tunisia) using annual data for the period 1996 to 2019 to highlight the interrelationship between the financial sector and the real side of the economy. Our choice of countries is solely based on the availability of data of the stock market of these countries. South Africa has the oldest (and most robust) stock market after Egypt whilst the markets in the remaining seven (7) are quite younger and liquidity constrained. In this study, the ratio of stock market capitalisation to GDP is our measure for stock market development, the ratio of broad money (M2) to GDP is our measure for financial deepening and also annual series of GDP as our measure of economic growth. Our choice of the ratio of stock market capitalisation to GDP as our measure for stock market development is based on the assumption that the entire market size is positively related to the capacity of the market to mobilise capital and diversify risk on a macro scale. We adopt the ratio of broad money (M2) to GDP as our measure of financial deepening; envisaging that economic growth will trigger or stimulate financial deepening.

The remainder of the paper is arraigned as follows; the literature review is presented in Section 2. The source of the data and methodology is presented in Section 3. Section 4 presents the empirical results, Section 5 presents the conclusion, recommendations and suggestion for further studies.

\section{Literature Review}

The desire or pursuit by national governments to establish, develop and promote strong and robust financial markets is based on the growing and available theoretical and empirical literature that argues in favor that, the development of stock market stimulates economic growth. Arestis et al. (2001) investigated the causal relationship between stock market development and economic growth in five (5) developed countries using time series methods after controlling for the impact of banking systems and the volatility in the stock market. They found evidence supporting the claim that though banks and stock markets promote 
economic growth, however the impact of the banking system is more significant. They therefore concluded that, the impact of the stock market on economic growth may have been overhyped in earlier studies that employed cross country growth regressions. Pradhan (2011) also examined the long run nexus between financial development and economic growth in India in a trivariate structure by including stock market development. He found that stock market development contributed significantly to the finance-growth inter-relationship. The study also established bidirectional relationship between financial development and economic growth whereas unidirectional relationship was found between economic growth and stock market development. Based on these findings, the study concluded that stock markets are core drivers of economic growth in India.

Yu et al. (2012) provided new evidence on the significance of financial development and stock market development in explaining economic growth across regions and income distributions. The results from the variance decomposition of annual economic growth rate provided evidence of a unique direction, timing and strength of the causal links based on the report from the granger causality test between financial development, stock development and economic growth. The call was therefore imperative to adopt concerted efforts to attain steady economic growth across different income groups and geographical regions.

Guglielmo et al. (2004) adopted the methods of Toda and Yamamoto (1995) to test for causality in vector autoregressive models to answer the question on the effect of stock market development on economic growth by examining the causal relationship between economic growth, financial development and stock market development. From a sample of seven (7) countries, they found that a well-functioning stock market can generate and stimulate economic growth in the long run. The results also lends support to theories and existing literature highlighting how a robust stock market can accelerate economic development by stimulating economic growth through accelerated capital accumulation. Nyasha and Odhiambo (2015) also investigated the effect of bank and market based financial development on economic growth in South Africa from the year 1980 to 2012. They employed the novel autoregressive distributed lag (ARDL) bounds estimation technique to investigate the causal relationship. They found the existence of a positive and significant linkage between the bank financial development indicator and growth in South Africa. The effect of the market based financial development indicator was however statistically insignificant. Their result was robust both in the short-run and long-run. Based on these findings; it was summarised that bank-based financial development are more paramount and central in propelling the real sectors of the South African economy than market-based financial development.

Ake (2010) employed times series data from the first quarter of 1995 to the fourth quarter of 2008 obtained from five (5) Euronext countries (Belgium, France, Portugal, Netherlands and United Kingdom). The technique of granger causality was employed to establish the causal linkage between stock market 
proxies through market capitalization, total trade value, turnover ratio and economic growth (GDP and FDI) for each country. For countries with highly active and liquid stock markets the study found positive causal relationship between stock market and economic growth whereas no causal relationship was recorded in countries with less active and illiquid small stock markets. In Japan, Jahfer and Inoue (2014) also employed the Johansen cointegration method and VECM to examine the long-run relationship among financial development, stock market development and economic growth. The test result from the Johansen cointegration method provided evidence of a long-run equilibrium relationship between the financial development, stock market development and economic growth. Evidence was also found that financial development, stock development caused economic growth however, no evidence of causality from economic growth of the long-run equilibrium relationship between the financial development, stock market development and economic growth was found. Their study also highlighted the fact that stock market development was central in the economic growth from the year 1974 to 2011 even though bank based financial development also contributed to growth; hence the effect of the stock market was found to the key in Japan's economic growth after 1974.

Capasso (2008) found strong theoretical support for the Modigliani and Miller (1958) theorem by focusing on challenging the idea of the presence of differences between the real world and financial sector assumed in the financial development literature. This is because, from the prevailing empirical evidence, most economists have allocated considerable importance to the causal linkage between financial variables and the mechanisms of real resource allocation. Hou \& Cheng (2010) used quarterly data spanning from 1971 to 2007 in Taiwan to examine the finance growth nexus by taking into consideration stock market development. Their results from the Johansen cointegration test established long run co-movement phenomenon among financial intermediation, stock market and economic development. From their empirical results, they found that the effect of stock market market capitalization to economic growth was significantly greater than the effect of banking financial development in the long run. Results from the Granger causality test based on VECM found further evidence of bi-directional causal link between financial development and economic growth in Taiwan Udegbunam (2002) adopted a simple model to examine the interrelationship among growth in industrial output to openness, stock market development and a set of control variables from 1970 to 1997 . He found very strong evidence of openness to world trade and stock market development as the key drivers of industrial growth in Nigeria. Matadeen and Seetanah (2015) analysed the significance and causal relationship between stock market developments, banking and economic growth in Mauritius using semi-annual data from 1988-2011. They employed the dynamic vector error correction estimation technique and found that stock market development in Mauritius positively and significantly affects economic growth in the long run. The effect however was not 
significant in the short run. In addition, they found that, through banking development, stock market development positively affects economic growth in the short run. Banking development also recorded positive and significant impact on economic growth in the short and long-run in Mauritius.

Taiwo et al. (2016) concluded that the easing and enhancement of stock market liquidity on the Nigerian stock exchange will consequently stimulate further economic growth. Their conclusion was based on the examining of effects of the capital market on economic growth in Nigeria using data spanning 1981 to 2014, through a vector error correction model. Further analysis from the cointegration test among the variables established that, stock market variables such as market capitalisation and total value of listed firms were critical determinants of economic growth in Nigeria Okoye et al. (2016) employed the econometric methodology of vector error correction model to examine the causal linkage between economic growth, capital market development and other stock market indicators from 1981 to 2014 in Nigeria. The results from the long-run estimate indicated that all the explanatory variables have negative and significant effect on economic growth; whereas the changes in stock market capitalisation, value traded and turnover ratio recorded more than average effect on economic growth. Their result from the granger causality test found causal impact of stock market capitalisation, value traded and turnover ratio on GDP. They also found the causality from GDP to inflation as uni-directional

Pinto et al. (2010) also examined the political factors driving the development of the stock market among various interest groups by challenging the prevailing assumption that left governments often frighten investors. After testing arguments of the different schools of thoughts on stock market capitalization in a panel of 85 countries spanning from 1975 to 2004, they found evidence in support of the school of thought that holds that left-leaning governments mostly favour higher stock market capitalisation as against their opponents on the right and centre of the political divide. Francis and Ofori (2015) highlighted the significance of political regimes in the finance-growth interrelationship. They established that political regimes significantly affect the size but not the liquidity of the security market. They also found no evidence of differences in the statistical significance in the volume of shares traded between autocracies and the remaining sample. The study further revealed that the effect of young democracy on financial development was negative for the period 1990 - 1999 but positive from 2000 to 2009 , signalling that the level of uncertainty in the financial market declines as democracy matures. Vo et al. (2016) found weak evidence in support of a strong causal link between stock mark development and economic growth in Vietnam during an examination of the significance of the financial structure in stimulating economic growth. No causal effect was recorded between the variables of the adopted model based on the Granger causality test. The report from the variance decomposition and the impulse response tests only provided evidence of one way effect from stock market capitalisation on the rate of eco- 
nomic growth, even though the effect was marginal

Handal (2013) adopted the Autoregressive Distributed Lag model to examine the causal links between stock market development and macroeconomic variables in Bahrain. The study found significance for the level of income, domestic investment, banking system development; private capital flows and stock market liquidity as the key drivers of stock market development in Bahrain and lends support to both the empirical and theoretical literature on stock market development and macroeconomic indicators nexus. Azarmi et al. (2005) found no evidence for the hypothesis that stock market development is correlated with economic growth in India for an event study from the year 1981 to 2001; based on their empirical examination of the relationship between stock market development and economic growth during the Indian financial market liberalization. They established support for the pre-liberalization sub-period of the significance of stock market development to economic growth. However, a negative relationship was found between stock market development and economic growth during the post-liberalization era. Nagaishi (1999) also examined the significance of the stock market on the growth of the Indian economy. The study made the following conclusions based on the empirical results 1) the stock market in India played no significant role in terms of domestic savings mobilization from the 1980s 2) attempts to deregulate the stock market further to attract more foreign investment may pose similar challenges such as volatility in the movement of domestic stock price and unstable balance of payment positions as experienced in Mexico, Korea and Thailand 3) the study also found no positive relationship between stock market development indicators and credit to the commercial sector by banks.

Pradhan (2018) adopted VECM and Granger causality test to investigate the presence of a long run linkage between stock market development and economic growth among G-20 economies from 1980 to 2015. The study found evidence of both unidirectional and bidirectional causality between stock market development and economic growth per capita. This evidence suggests that to maintain steady development within the G-20 countries, policymakers must acknowledge the dichotomy between stock market development and economic growth per capita.

\section{Data Sources and Definition of Variables}

The data set adopted for this study is time series annual data obtained from the website of the World Development Indicators (WDI) for the period 1996 to 2019. The variables for this study are broad money (M2) to GDP ratio (M2/GDP ratio) as our measure of financial deepening, economic growth (GDP), Savings to GDP ratio (Savings/GDP ratio), private sector credit to GDP ratio (PSC/GDP) ratio, annual inflation rate, annual official exchange rate and stock market capitalization to GDP ratio (STMCAP/GDP ratio) as our stock market development indicator. 


\subsection{Model Specification}

In a standard macroeconomic model, the theory of money demand and its determinants is expressed as:

$\mathrm{M} 2 / \mathrm{GDP}=f(\operatorname{lnGDP}$, Savings/GDP, PSC/GDP, Infl, Exch, STMCAP/GDP $)$

where:

M2/GDP is the measure of financial deepening.

Savings/GDP is the annual Savings to GDP ratio.

PSC/GDP is the annual total credit to the private sector credit to GDP ratio.

lnGDP is the natural log of annual gross domestic product; our economic growth indicator variable.

Infl is the annual general price level (inflation).

Exch is the annual official exchange rate.

STMCAP/GDP is the annual stock market capitalization to GDP ratio as our stock market development indicator.

Equation (1) is formally expressed as:

$$
\begin{aligned}
(\mathrm{M} 2 / \mathrm{GDP})_{i t}= & \beta_{0}+\beta_{1}(\operatorname{lnGDP})_{i t}+\beta_{2}(\text { Savings/GDP })_{i t}+\beta_{3}(\mathrm{PSC} / \mathrm{GDP})_{i t} \\
& +\beta_{4}(\mathrm{Infl})_{i t}+\beta_{5}(\text { Exch })_{i t}+\beta_{6}(\mathrm{STMCAP} / \mathrm{GDP})_{i t}+\varepsilon_{i t}
\end{aligned}
$$

where, $\varepsilon_{i t}$ is the stochastic error term.

The parameter $\beta_{1}$ reflects the semi-elasticity of economic growth with respect to financial deepening (M2/GDP). $\beta_{2}, \beta_{3}, \beta_{4}, \beta_{5}$ and $\beta_{6}$ also measures the effect of changes insavings to GDP ratio (Savings/GDP), private sector credit to GDP ratio (PSC/GDP), inflation, exchange rate and thestock market development indicator (STMCAP/GDP) respectively.

A negative relationship is expected between economic growth indicator (lnGDP) and the financial deepening indicator. Whereas a positive relationship is expected between stock market development (STMCAP/GDP) and financial deepening (M2/GDP).

\subsection{ARDL Model Specification}

The study adopts the ARDL bounds cointegration technique developed by Pesaran et al. (2001) to investigate the presence of long run linkages between financial deepening, economic growth and stock market development among other variables in eight (8) African countries. The choice of study methodology is based on the reason that it provides consistent estimates, able to detect and overcome the problems of autocorrelation and endogeneity that is most likely to arise.

The ADRL $\left(p, q_{1}, q_{2}, \cdots, q_{k}\right)$ model specification is stated as follows (Pesaran et al., 2001):

$$
\alpha(L, p) y_{i t}=\mu+\sum_{i=1}^{k} \beta_{i}(L, p) \chi_{i t}+\lambda^{\prime} W_{i t}+\varepsilon_{i t}, \quad \forall t=1, \cdots, n
$$

where; 


$$
\begin{gathered}
\alpha(L, p)=1-\alpha_{1} L-\alpha_{2} L^{2}-\cdots-\alpha_{p} L^{p} \\
\beta_{i}\left(L, q_{i}\right)=\beta_{i 0}+\beta_{i 1} L+\beta_{i 2} L^{2}+\cdots+\beta_{i q_{i}} L^{q_{i}}, \forall i=1,2, \cdots, k
\end{gathered}
$$

$y_{t}=$ dependent variable.

$\mu=$ constant term.

$L=$ lag operator.

$w_{t}=s \times 1$ vector of deterministic variables such as intercept term

time trends, or exogenous variables with fixed lags.

The summary statistics of all the variables for this study is reported in Table 1 above for a 216 country-year observations from 1996 to 2019 for eight (8) countries. Annual inflation rate has the lowest mean and the natural log of GDP (lnGDP) has the lowest standard deviation of 6.974 and 4.442 respectively. The means and standard deviations of the other variables (M2/GDP, lnGDP, Savings/GDP, PSC/GDP, EXCH and STMCAP/GDP) are 55.184, $27.403,26.585,48.69,41.355$ and 44.565 and 26.212, 2.296, 23.951, 39.465, 55 and 68.68 .

The correlation matrix among the variables of this study is reported in Table 2. The report shows that except for three correlation coefficients, all others are weakly and statistically significant at $5 \%$.

We present the result of the Im-Pesaran-Shin unit-root test of the panel is reported in Table 3. We report that Savings/GDP ratio and Inflation rate are not

Table 1. Descriptive statistics.

\begin{tabular}{cccccc}
\hline Variable & Obs & Mean & Std.Dev. & Min & Max \\
\hline M2/GDP & 216 & 55.184 & 26.212 & 9.063 & 119.709 \\
LnGDP & 216 & 27.403 & 2.296 & 23.806 & 31.909 \\
Savings/GDP & 216 & 26.585 & 23.951 & -4.245 & 98.136 \\
PSC/GDP & 216 & 48.69 & 39.465 & 3.907 & 160.125 \\
INFLATION & 216 & 6.974 & 4.442 & -0.692 & 29.507 \\
EXCH & 216 & 41.355 & 55 & 0.973 & 306.921 \\
STMCAP/GDP & 216 & 44.565 & 68.68 & 0.053 & 352.156 \\
\hline
\end{tabular}

\begin{tabular}{|c|c|c|c|c|c|c|c|}
\hline Variables & (1) & (2) & (3) & (4) & (5) & (6) & (7) \\
\hline (1) M2GDP & 1.000 & & & & & & \\
\hline (2) $\operatorname{lnGDP}$ & -0.068 & 1.000 & & & & & \\
\hline (3) SavingsGDP & $0.359^{*}$ & $0.382^{*}$ & 1.000 & & & & \\
\hline (4) PSCGDP & $0.547^{\star}$ & $-0.146^{*}$ & $-0.174^{*}$ & 1.000 & & & \\
\hline (5) INFLATION & $-0.307^{\star}$ & $0.358^{\star}$ & $0.165^{\star}$ & $-0.320^{*}$ & 1.000 & & \\
\hline (6) $\mathrm{EXCH}$ & $-0.340^{\star}$ & $0.706^{\star}$ & -0.056 & $-0.438^{\star}$ & $0.296^{\star}$ & 1.000 & \\
\hline (7) STMCAPGDP & $0.367^{\star}$ & $0.165^{\star}$ & 0.018 & $0.841^{*}$ & $-0.137^{\star}$ & $-0.262^{\star}$ & 1.000 \\
\hline
\end{tabular}

Table 2. Pairwise correlations.

*Shows significance at the 0.05 level. 
Table 3. Im-Pesaran-Shin unit-root test.

\begin{tabular}{ccccc}
\hline \multirow{2}{*}{ Variable } & \multicolumn{2}{c}{ Level } & \multicolumn{2}{c}{$1^{\text {ST }}$ Difference } \\
\cline { 2 - 5 } & Statistic & p-value & Statistic & p-value \\
\hline M2/GDP & $-6.0568^{* * *}$ & 0.0000 & $-5.6662^{* * *}$ & 0.0000 \\
LnGDP & $-4.0977^{* * *}$ & 0.0000 & $-14.6187^{* * *}$ & 0.0000 \\
Savings/GDP & 0.2138 & 0.5847 & $-19.5821^{* * *}$ & 0.0000 \\
PSC/GDP & $-7.8584^{* * *}$ & 0.0000 & $-9.0801^{* * *}$ & 0.0000 \\
INFLATION & -0.1225 & 0.4512 & $-4.8953^{* * *}$ & 0.0000 \\
EXCH & $-8.5015^{* * *}$ & 0.0000 & $-10.4282^{* * *}$ & 0.0000 \\
STMCAP/GDP & $-5.9326^{* * *}$ & 0.0000 & $-8.0976^{* * *}$ & 0.0000 \\
\hline
\end{tabular}

stationary at level; however, after their first difference they attained stationarity.

Test for cointegration within the panel: (xtpedroni M2/GDP lnGDP Savings GDP PSCGDP INFLATION EXCH STMCAPGDP INTEREST, nopdols).

Pedroni's cointegration tests:

No. of Panel units: 9 Regressors: 7.

No. of obs.: 216 Avg obs. per unit: 24.

Data has been time-demeaned.

All test statistics are distributed $\mathrm{N}(0,1)$, under a null of no co-integration, and diverge to negative infinity (save for panel v). The summary report from the Pedroni co-integration test of the panel is reported in Table 4. The summary report provides evidence of the presence of long-run relationship for the panel variables.

Results of the Autoregressive Bounds Test for the times series analysis using $\operatorname{lnGDP}$ as dependent variable.

Table 5 is the summary report of the ARDL bounds test indicating the maximum lags for each country. The result for each country based on the F-statistic in column 3 in interpreted in column 4 as co-integrated or not co-integrated. Five (5) countries (Nigeria, Algeria, Namibia, Kenya and Mauritius) have co-integrated series.

Results of the Autoregressive Bounds Test for the times series analysis using M2/GDP as dependent variable.

Table 6 is the summary report of the ARDL bounds test indicating the maximum lags for each country. The result for each country based on the F-statistic in column 3 in interpreted in column 4 as co-integrated or not co-integrated. Four (4) countries (Tunisia, Algeria, South Africa and Eswatini) have co-integrated series.

\section{Results}

Table 7 is the report of the regression results with M2/GDP (financial deepening indicator variable as the dependent variable for countries with conitegrated series. 
Table 4. Pedroni'scointegration tests.

\begin{tabular}{ccc}
\hline Test Stats. & Panel & Group \\
\hline $\mathrm{v}$ & -1.918 & \\
rho & 3.732 & 4.683 \\
$\mathrm{~T}$ & 1.691 & 0.7818 \\
$\mathrm{adf}$ & 3.612 & 2.782 \\
\hline
\end{tabular}

Table 5. ARDL bounds test.

\begin{tabular}{|c|c|c|c|}
\hline Country & Lags & F-stats & Remark \\
\hline Nigeria & 2112222 & $108.516^{* * *}$ & Co-integrated \\
\hline Tunisia & 2111222 & 3.263 & Not Co-integrated \\
\hline Algeria & 2221221 & $21.225^{* * *}$ & Co-integrated \\
\hline Namibia & 2222121 & $9.429^{* * *}$ & Co-integrated \\
\hline South Africa & 2122222 & 1.954 & Not Co-integrated \\
\hline Eswatini & 2222212 & 3.673 & Not Co-integrated \\
\hline Kenya & 2220222 & $36.208^{* * *}$ & Co-integrated \\
\hline Mauritius & 2122222 & $118.344^{\star * *}$ & Co-integrated \\
\hline
\end{tabular}

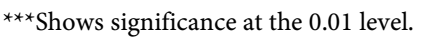

Table 6. ARDL bounds test.

\begin{tabular}{|c|c|c|c|}
\hline Country & Lags & F-stats & Remark \\
\hline Nigeria & 1202000 & 2.692 & Not Co-integrated \\
\hline Tunisia & 1220222 & $22.498^{\star * *}$ & Co-integrated \\
\hline Algeria & 2212220 & $10.944^{* * *}$ & Co-integrated \\
\hline Namibia & 1200011 & 3.664 & Not Co-integrated \\
\hline South Africa & 2222222 & $1.2 \mathrm{e}+07^{* * *}$ & Co-integrated \\
\hline Eswatini & 2222222 & $1.8 \mathrm{e}+09^{* * *}$ & Co-integrated \\
\hline Kenya & 1212222 & 2.546 & Not Co-integrated \\
\hline Mauritius & 2212212 & 3.768 & Not Co-integrated \\
\hline
\end{tabular}

${ }^{* * *}$ shows significance at the 0.01 level.

As reported in Table 7, the long run semi-elasticity coefficients of lnGDP are statistically significant at $1 \%$ for in Tunisia, South Africa and Eswatini except for Algeria. The result indicates that the relationship between economic growth (lnGDP) and financial deepening (M2/GDP) is positive in Tunisia, South Africa but negative in Eswatini. The elasticity coefficient economic with respect to financial deepening is $34.860,6.615,-26.411$ for Tunisia, South Africa and respectively. We also find the coefficient of the long run stock market development index (STMCAP/GDP) to be negative and statistically significant at $1 \%$ for Tunisia, South Africa and Eswatini except for Algeria. Meanwhile the short run semi-elasticity coefficient of financial deepening with respect to economic growth (lnGDP) is statistically significant and positive in South Africa but 
Table 7. Regression results.

\begin{tabular}{|c|c|c|c|c|}
\hline & Tunisia & Algeria & South A. & Eswatini \\
\hline & M2/GDP & M2/GDP & M2/GDP & $\mathrm{M} 2 / \mathrm{GDP}$ \\
\hline \multirow[t]{2}{*}{ L.M2/GDP } & $-1.570^{* * *}$ & -0.093 & $-1.710^{* * *}$ & $-1.049^{* * *}$ \\
\hline & $(0.209)$ & $(0.303)$ & $(0.000)$ & $(0.000)$ \\
\hline \multirow[t]{2}{*}{ LR:lnGDP } & $34.860^{* * *}$ & 441.659 & $6.615^{\star \star \star}$ & $-26.411^{\star * *}$ \\
\hline & (1.179) & $(1388.194)$ & $(0.007)$ & $(0.002)$ \\
\hline \multirow[t]{2}{*}{ LR:Savings/GDP } & $1.111^{\star \star \star}$ & -4.234 & $-0.613^{\star * \star}$ & $-0.381^{\star \star \star}$ \\
\hline & $(0.116)$ & $(13.386)$ & $(0.001)$ & $(0.000)$ \\
\hline \multirow[t]{2}{*}{ LR:PSC/GDP } & $0.731^{\star * \star}$ & -31.618 & $0.893^{* * *}$ & $1.154^{* * *}$ \\
\hline & $(0.069)$ & (111.931) & $(0.000)$ & $(0.000)$ \\
\hline \multirow[t]{2}{*}{ LR:INFLATION } & 0.194 & -19.247 & $-0.359^{* * *}$ & $-0.456^{* * *}$ \\
\hline & $(0.381)$ & $(62.504)$ & $(0.000)$ & $(0.000)$ \\
\hline \multirow[t]{2}{*}{ LR:EXCH } & $3.864^{* *}$ & 5.469 & $-0.536^{* * *}$ & $1.745^{\star * \star}$ \\
\hline & $(1.181)$ & $(19.062)$ & $(0.000)$ & $(0.000)$ \\
\hline \multirow[t]{2}{*}{ LR:STMCAP/GDP } & $-0.733^{* * *}$ & -50.551 & $-0.023^{* * *}$ & $-0.159^{* * *}$ \\
\hline & $(0.120)$ & (168.195) & $(0.000)$ & $(0.000)$ \\
\hline \multirow[t]{2}{*}{ SR:D.lnGDP } & -25.992 & -88.916 & $5.413^{\star * \star}$ & $-4.209^{\star * \star}$ \\
\hline & $(22.158)$ & $(61.854)$ & $(0.076)$ & $(0.005)$ \\
\hline \multirow[t]{2}{*}{ SR:LD.lnGDP } & $-51.886^{\star}$ & $-175.108^{\star *}$ & $-51.999^{* * *}$ & $90.925^{\star * *}$ \\
\hline & $(19.359)$ & $(45.737)$ & $(0.044)$ & $(0.003)$ \\
\hline \multirow[t]{2}{*}{ SR:D.Savings/GDP } & $-1.919^{* * *}$ & $-1.085^{\star * *}$ & $-0.423^{* * *}$ & $0.421^{\star * *}$ \\
\hline & $(0.395)$ & $(0.204)$ & $(0.002)$ & $(0.000)$ \\
\hline \multirow[t]{2}{*}{ SR:LD.Savings/GDP } & -0.854 & & $-3.951^{* * *}$ & $-0.093^{\star * \star}$ \\
\hline & $(0.441)$ & & $(0.001)$ & $(0.000)$ \\
\hline \multirow[t]{2}{*}{ SR:D.INFLATION } & $0.831^{* *}$ & $1.027^{\star}$ & $-0.523^{* * *}$ & $0.252^{\star * \star}$ \\
\hline & $(0.268)$ & $(0.424)$ & $(0.001)$ & $(0.000)$ \\
\hline \multirow[t]{2}{*}{ SR:LD.INFLATION } & $1.197^{\star \star \star}$ & 0.469 & $-1.063^{* * *}$ & $0.173^{\star \star \star}$ \\
\hline & $(0.256)$ & $(0.288)$ & $(0.000)$ & $(0.000)$ \\
\hline \multirow[t]{2}{*}{ SR:D.EXCH } & $6.743^{\star}$ & $-0.660^{\star \star \star}$ & $-3.483^{\star * *}$ & $-1.108^{\star * *}$ \\
\hline & $(2.553)$ & $(0.127)$ & $(0.001)$ & $(0.000)$ \\
\hline \multirow[t]{2}{*}{ SR:LD.EXCH } & 5.000 & $-0.427^{\star *}$ & $0.292^{* * *}$ & $-0.276^{* * *}$ \\
\hline & $(2.595)$ & $(0.116)$ & $(0.002)$ & $(0.000)$ \\
\hline \multirow[t]{2}{*}{ SR:D.STMCAP/GDP } & $0.577^{* *}$ & & $0.019^{* * *}$ & $0.262^{\star * *}$ \\
\hline & $(0.205)$ & & $(0.000)$ & $(0.000)$ \\
\hline \multirow[t]{2}{*}{ SR:LD.STMCAP/GDP } & $0.330^{* *}$ & & $-0.012^{* * *}$ & $0.398^{\star * *}$ \\
\hline & $(0.117)$ & & $(0.000)$ & $(0.000)$ \\
\hline SR:LD.M2/GDP & & $-0.455^{\star *}$ & $2.106^{* * *}$ & $0.382^{* * *}$ \\
\hline
\end{tabular}




\section{Continued}

\begin{tabular}{|c|c|c|c|c|}
\hline & & $(0.152)$ & $(0.000)$ & $(0.000)$ \\
\hline \multirow[t]{2}{*}{ SR:D.PSC/GDP } & & 1.725 & $-1.241^{\star * \star}$ & $-1.419^{* * *}$ \\
\hline & & $(0.869)$ & $(0.000)$ & $(0.000)$ \\
\hline \multirow[t]{2}{*}{ SR:LD.PSC/GDP } & & $2.380^{* *}$ & $-0.798^{\star * *}$ & $-0.873^{\star * *}$ \\
\hline & & $(0.558)$ & $(0.000)$ & $(0.000)$ \\
\hline \multirow[t]{2}{*}{ SR:_cons } & $-1361.764^{* * *}$ & $-1155.862^{\star \star}$ & $-375.918^{* * *}$ & $663.767^{* * *}$ \\
\hline & (194.575) & $(345.100)$ & $(0.360)$ & $(0.035)$ \\
\hline Obs. & 22 & 22 & 22 & 22 \\
\hline R-squared & 0.861 & 0.907 & 0.778 & 0.875 \\
\hline
\end{tabular}

Standard errors are in parenthesis. ${ }^{\star *} \mathrm{p}<0.01,{ }^{* *} \mathrm{p}<0.05,{ }^{\star} \mathrm{p}<0.1$.

negative in Eswatini. This means that whilst stock market development positively and significantly affect financial development in South Africa, it have a negative effect in Eswatini.

Table 8 is the report of the regression results with M2/GDP (financial deepening indicator variable) as the dependent variable for countries without conitegrated series.

Table 8 is the report of the regression results with M2/GDP (financial deepening indicator variable as the dependent variable for countries without co-integrated series, however the last column of table is the regression results of the entire panel. The result from the short run regression indicates that the semi-elasticity coefficient of economic growth (lnGDP) is only significant and negative in Mauritius at $10 \%$. The short run coefficient of stock market development is also negative and statistically significant at 5\% in Mauritius. The result from the panel regression indicates that, economic growth is significant and negatively related to financial deepening in Africa. The relation between stock market development (STMCAP/GDP) and financial deepening (M2/GDP) is positive and statistically significant at $10 \%$.

Table 9 is the results of the granger causality test between economic growth (lnGDP) and stock market development (STMCAP/GDP) for the series in Nigeria. The regression result indicates the presence of unidirectional causality from economic growth (lnGDP) to stock market development (STMCAP/GDP) in Nigeria.

Table 10 is the results of the granger causality test between economic growth (lnGDP) and stock market development (STMCAP/GDP) for the series in Tunisia. The regression result indicates the presence of unidirectional causality from economic growth (lnGDP) to stock market development (STMCAP/GDP) in Tunisia.

Table 11 is the results of the granger causality test between economic growth (lnGDP) and stock market development (STMCAP/GDP) for the series in Algeria. The regression result indicates the presence of bi-directional causality 
Table 8. Regression results.

\begin{tabular}{|c|c|c|c|c|c|}
\hline & Nigeria & Namibia & Kenya & Mauritius & Panel \\
\hline & M2/GDP & M2/GDP & M2/GDP & $\mathrm{M} 2 / \mathrm{GDP}$ & D.M2/GDP \\
\hline \multirow[t]{2}{*}{ L.M2/GDP } & $0.469^{\star *}$ & 0.074 & 1.292 & $3.813^{* *}$ & \\
\hline & $(0.208)$ & $(0.270)$ & $(0.974)$ & $(0.920)$ & \\
\hline \multirow[t]{2}{*}{ L2.M2/GDP } & & & & $-4.232^{\star *}$ & \\
\hline & & & & $(1.204)$ & \\
\hline \multirow[t]{2}{*}{ LnGDP } & 2.370 & -47.464 & -79.669 & $-527.472^{*}$ & $-5.719^{\star *}$ \\
\hline & $(15.248)$ & $(46.977)$ & $(54.102)$ & $(173.534)$ & $(2.543)$ \\
\hline \multirow[t]{2}{*}{ L.lnGDP } & -40.548 & -57.446 & -76.325 & $1169.228^{\star *}$ & \\
\hline & $(29.084)$ & $(70.122)$ & $(72.614)$ & $(323.513)$ & \\
\hline \multirow[t]{2}{*}{ L2.lnGDP } & $41.234^{\star}$ & $147.136^{* * *}$ & 132.318 & $-660.692^{\star *}$ & \\
\hline & $(18.523)$ & $(43.598)$ & $(77.075)$ & (179.338) & \\
\hline \multirow[t]{2}{*}{ Savings/GDP } & 0.002 & $-1.078^{\star *}$ & -1.250 & 2.848 & -0.046 \\
\hline & $(0.070)$ & $(0.377)$ & $(0.880)$ & $(1.265)$ & $(0.159)$ \\
\hline \multirow[t]{2}{*}{ PSC/GDP } & $1.203^{* * *}$ & -0.402 & 0.122 & $0.338^{*}$ & $0.982^{* * *}$ \\
\hline & $(0.217)$ & (1.194) & $(0.800)$ & $(0.112)$ & $(0.146)$ \\
\hline \multirow[t]{2}{*}{ L.PSC/GDP } & $-1.049^{* * *}$ & & 0.072 & $-0.794^{* *}$ & \\
\hline & $(0.288)$ & & $(0.551)$ & $(0.203)$ & \\
\hline \multirow[t]{2}{*}{ L2.PSC/GDP } & $0.726^{\star * *}$ & & 0.219 & $1.411^{\star}$ & \\
\hline & $(0.219)$ & & $(0.585)$ & $(0.453)$ & \\
\hline \multirow[t]{2}{*}{ INFLATION } & 0.007 & -1.582 & -0.785 & $3.384^{\star}$ & -0.120 \\
\hline & $(0.115)$ & $(1.473)$ & $(0.405)$ & $(1.336)$ & $(0.181)$ \\
\hline \multirow[t]{2}{*}{ EXCH } & -0.009 & $-2.407^{\star *}$ & -0.046 & $-4.704^{*}$ & 0.051 \\
\hline & $(0.012)$ & $(0.984)$ & $(0.125)$ & $(1.490)$ & $(0.040)$ \\
\hline \multirow[t]{2}{*}{ STMCAP/GDP } & -0.062 & -0.157 & -0.109 & $-0.540^{* *}$ & $0.197^{*}$ \\
\hline & $(0.096)$ & $(0.249)$ & $(0.217)$ & $(0.166)$ & $(0.101)$ \\
\hline \multirow[t]{2}{*}{ L.EXCH } & & -1.569 & 0.240 & $5.829^{* *}$ & \\
\hline & & $(0.875)$ & $(0.163)$ & $(1.568)$ & \\
\hline \multirow[t]{2}{*}{ L2.EXCH } & & & 0.004 & & \\
\hline & & & $(0.226)$ & & \\
\hline \multirow[t]{2}{*}{ L.Savings/GDP } & & & -0.824 & $-9.619^{* *}$ & \\
\hline & & & $(0.796)$ & $(2.960)$ & \\
\hline \multirow[t]{2}{*}{ L.INFLATION } & & & -0.662 & $8.243^{* *}$ & \\
\hline & & & $(0.449)$ & $(2.215)$ & \\
\hline \multirow[t]{2}{*}{ L2.INFLATION } & & & 0.064 & 1.497 & \\
\hline & & & $(0.117)$ & $(0.651)$ & \\
\hline \multirow[t]{2}{*}{ L.STMCAP/GDP } & & & 0.737 & $-0.436^{*}$ & \\
\hline & & & $(0.422)$ & $(0.161)$ & \\
\hline
\end{tabular}




\section{Continued}

\begin{tabular}{|c|c|c|c|c|c|}
\hline \multirow[t]{2}{*}{ L2.STMCAP/GDP } & & & 0.577 & $-0.717^{\star *}$ & \\
\hline & & & $(0.412)$ & $(0.181)$ & \\
\hline \multirow[t]{2}{*}{ _cons } & -91.345 & $-938.012^{*}$ & 646.844 & 662.655 & \\
\hline & $(103.437)$ & $(507.681)$ & $(317.341)$ & $(498.737)$ & \\
\hline \multirow[t]{2}{*}{ SR:_ec } & & & & & $-0.194^{\star \star}$ \\
\hline & & & & & $(0.079)$ \\
\hline \multirow[t]{2}{*}{ SR:D.lnGDP } & & & & & $-26.769^{*}$ \\
\hline & & & & & $(15.184)$ \\
\hline \multirow[t]{2}{*}{ SR:D.Savings/GDP } & & & & & -0.079 \\
\hline & & & & & $(0.163)$ \\
\hline \multirow[t]{2}{*}{ SR:D.PSCGDP } & & & & & 0.263 \\
\hline & & & & & $(0.240)$ \\
\hline \multirow[t]{2}{*}{ SR:D.INFLATION } & & & & & -0.239 \\
\hline & & & & & $(0.235)$ \\
\hline \multirow[t]{2}{*}{ SR:D.EXCH } & & & & & -0.149 \\
\hline & & & & & $(0.169)$ \\
\hline \multirow[t]{2}{*}{ SR:D.STMCAP/GDP } & & & & & -0.227 \\
\hline & & & & & $(0.283)$ \\
\hline \multirow[t]{2}{*}{ SR:_cons } & & & & & $35.679^{* * *}$ \\
\hline & & & & & $(13.585)$ \\
\hline Obs. & 22 & 22 & 22 & 22 & 184 \\
\hline $\mathrm{R}$-squared & 0.869 & 0.732 & 0.678 & 0.898 & 0.0788 \\
\hline
\end{tabular}

Standard errors are in parenthesis, ${ }^{* *} \mathrm{p}<0.01,{ }^{* *} \mathrm{p}<0.05,{ }^{*} \mathrm{p}<0.1$

Table 9. Regression for Nigeria.

\begin{tabular}{|c|c|c|c|c|c|c|c|}
\hline $\operatorname{lnGDP}$ & Coef. & Std. & Err. & $\mathrm{T}$ & $P>t$ & [95\% Conf. & Interval] \\
\hline \multicolumn{8}{|l|}{$\operatorname{lnGDP}$} \\
\hline L1. & 0.9729493 & 0.0169344 & 57.45 & 0.000 & 0.9376247 & 1.008274 & \\
\hline \multicolumn{8}{|c|}{ STMCAP/GDP } \\
\hline L1. & -0.0012176 & 0.0010166 & -1.20 & 0.245 & -0.0033381 & 0.000903 & \\
\hline cons & 0.91379 & 0.5332365 & 1.71 & 0.102 & -0.1985218 & 2.026102 & \\
\hline
\end{tabular}

between economic growth (lnGDP) and stock market development (STMCAP/ GDP in Algeria.

Table 12 is the results of the granger causality test between economic growth (lnGDP) and stock market development (STMCAP/GDP) for the series in Namibia. The regression result indicates the presence of bi-directional causality between economic growth (lnGDP) and stock market development (STMCAP/GDP) 
Table 10. Regression for Tunisia.

\begin{tabular}{|c|c|c|c|c|c|c|}
\hline $\operatorname{lnGDP}$ & Coef. & Std. & Err. & $\mathrm{T}$ & $P>t$ & [95\% Conf. Interval] \\
\hline \multicolumn{7}{|l|}{$\operatorname{lnGDP}$} \\
\hline L1. & 0.9716257 & 0.0188289 & 51.60 & 0.000 & 0.9323494 & 1.010902 \\
\hline \multicolumn{7}{|c|}{ STMCAP/GDP } \\
\hline L1. & -0.0014445 & 0.0008618 & -1.68 & 0.109 & -0.0032421 & 0.0003532 \\
\hline cons & 0.7568805 & 0.4558741 & 1.66 & 0.112 & -0.1940562 & 1.707817 \\
\hline
\end{tabular}

Table 11. Regression for Algeria.

\begin{tabular}{cccccccc}
\hline $\operatorname{lnGDP}$ & Coef. & Std. & Err. & $\mathrm{T}$ & $\mathrm{P}>\mathrm{t}$ & [95\% Conf. Interval] \\
\hline $\operatorname{lnGDP}$ & & & & & & \\
L1. & 0.9420019 & 0.0193965 & 48.57 & 0.000 & 0.9015416 & 0.9824623 & \\
STMCAP/GDP & & & & & & \\
L1. & 1.731677 & 0.5689682 & 3.04 & 0.006 & 0.5448302 & 2.918524 \\
cons & 0.7568805 & 0.4558741 & 1.66 & 0.112 & -0.1940562 & 1.707817 \\
\hline
\end{tabular}

Table 12. Regression for Algeria.

\begin{tabular}{cccccccc}
\hline $\operatorname{lnGDP}$ & Coef. & Std. & Err. & $\mathrm{T}$ & $\mathrm{P}>\mathrm{t}$ & [95\% Conf. & Interval] \\
\hline $\operatorname{lnGDP}$ & & & & & & & \\
L1. & 0.9896409 & 0.0207514 & 47.69 & 0.000 & 0.9463544 & 1.032927 & \\
STMCAP/GDP & & & & & & \\
L1. & -0.0023999 & 0.001116 & -2.15 & 0.044 & -0.0047278 & -0.0000721 \\
cons & 0.7568805 & 0.4558741 & 1.66 & 0.112 & -0.1940562 & 1.707817 \\
\hline
\end{tabular}

in Namibia.

Table 13 is the results of the granger causality test between economic growth (lnGDP) and stock market development (STMCAP/GDP) for the series in South Africa. The regression result indicates the presence of uni-directional causality from economic growth (lnGDP) to stock market development (STMCAP/GDP) in South Africa.

Table 14 is the results of the granger causality test between economic growth (lnGDP) and stock market development (STMCAP/GDP) for the series in Eswatini. The regression result indicates the presence of uni-directional causality from economic growth (lnGDP) to stock market development (STMCAP/GDP) in Eswatini.

Table 15 is the results of the granger causality test between economic growth (lnGDP) and stock market development (STMCAP/GDP) for the series in Kenya. The regression result indicates the presence of uni-directional causality from economic growth (lnGDP) to stock market development (STMCAP/GDP) in Kenya. 
Table 13. Reg for south Africa.

\begin{tabular}{|c|c|c|c|c|c|c|}
\hline $\operatorname{lnGDP}$ & Coef. & Std. & Err. & $\mathrm{T}$ & $P>t$ & [95\% Conf. Interval] \\
\hline \multicolumn{7}{|l|}{$\operatorname{lnGDP}$} \\
\hline L1. & 0.9337831 & 0.0278326 & 33.55 & 0.000 & 0.8757252 & 0.9918409 \\
\hline \multicolumn{7}{|c|}{ STMCAP/GDP } \\
\hline L1. & 0.0001258 & 0.0000895 & 1.41 & 0.175 & -0.0000609 & 0.0003125 \\
\hline cons & 1.887051 & 0.7791166 & 2.42 & 0.025 & 0.2618419 & 3.512259 \\
\hline
\end{tabular}

Table 14. Regression for Eswatini.

\begin{tabular}{cccccccc}
\hline $\operatorname{lnGDP}$ & Coef. & Std. & Err. & $\mathrm{T}$ & $\mathrm{P}>\mathrm{t}$ & [95\% Conf. & Interval] \\
\hline $\operatorname{lnGDP}$ & & & & & & & \\
L1. & 0.9805633 & 0.0180258 & 54.40 & 0.000 & 0.9429622 & 1.018164 & \\
STMCAP/GDP & & & & & & & \\
L1. & -0.0001988 & 0.0006186 & -0.32 & 0.751 & -0.0014891 & 0.0010915 & \\
cons & 0.500354 & 0.4384261 & 1.14 & 0.267 & -0.4141869 & 1.414895 & \\
\hline
\end{tabular}

Table 15. Regression for Kenya.

\begin{tabular}{|c|c|c|c|c|c|c|c|}
\hline $\operatorname{lnGDP}$ & Coef. & Std. & Err. & $\mathrm{T}$ & $P>t$ & [95\% Conf. & Interval] \\
\hline \multicolumn{8}{|l|}{$\operatorname{lnGDP}$} \\
\hline L1. & 1.03019 & 0.0140152 & 73.50 & 0.000 & 1.000955 & 1.059426 & \\
\hline \multicolumn{8}{|c|}{ STMCAP/GDP } \\
\hline L1. & 0.0007312 & 0.0004342 & 1.68 & 0.108 & -0.0001745 & 0.001637 & \\
\hline cons & -0.8401167 & 0.3977529 & -2.11 & 0.047 & -1.669815 & -0.0104187 & \\
\hline
\end{tabular}

Table 16 is the results of the granger causality test between economic growth (lnGDP) and stock market development (STMCAP/GDP) for the series in Mauritius. The regression result indicates the presence of bi-directional causality between economic growth (lnGDP) and stock market development (STMCAP/GDP) in Mauritius.

Table 16. Regression for Mauritius.

\begin{tabular}{cccccccc}
\hline $\operatorname{lnGDP}$ & Coef. & Std. & Err. & $\mathrm{T}$ & $\mathrm{P}>\mathrm{t}$ & {$[95 \%$ Conf. } & Interval] \\
\hline $\ln$ GDP & & & & & & & \\
L1. & 0.9631065 & 0.0144669 & 66.57 & 0.000 & 0.9329291 & 0.9932838 & \\
STMCAP/GDP & & & & & & \\
L1. & 0.0003538 & 0.0001888 & 1.87 & 0.076 & -0.0000399 & 0.0007475 \\
cons & 0.987915 & 0.3714859 & 2.66 & 0.015 & 0.2130089 & 1.762821
\end{tabular}

The Granger causality test for the panel series between STMCAP/GDP and $\operatorname{lnGDP}$. 
Table 17. Regression results.

\begin{tabular}{|c|c|c|c|c|c|}
\hline & Nigeria & Algeria & Namibia & Kenya & Mauritius \\
\hline & $\operatorname{lnGDP}$ & $\operatorname{lnGDP}$ & $\operatorname{lnGDP}$ & $\operatorname{lnGDP}$ & $\operatorname{lnGDP}$ \\
\hline \multirow[t]{2}{*}{ L.lnGDP } & $-0.122^{* * *}$ & -0.045 & $0.969^{* *}$ & -0.008 & $-0.058^{\star *}$ \\
\hline & $(0.012)$ & $(0.044)$ & $(0.182)$ & $(0.028)$ & $(0.011)$ \\
\hline \multirow[t]{2}{*}{ LR:Savings/GDP } & $-0.038^{\star * *}$ & -0.093 & 0.000 & -3.554 & $-0.238^{\star *}$ \\
\hline & $(0.004)$ & $(0.091)$ & $(0.003)$ & $(12.311)$ & $(0.045)$ \\
\hline \multirow[t]{2}{*}{ LR:PSC/GDP } & 0.005 & -0.530 & $0.062^{* * *}$ & 0.682 & $0.030^{* *}$ \\
\hline & $(0.010)$ & $(0.594)$ & $(0.004)$ & $(2.115)$ & $(0.005)$ \\
\hline \multirow[t]{2}{*}{ LR:INFLATION } & $-0.018^{\star *}$ & -0.084 & $0.098^{* * *}$ & -0.492 & $0.428^{* *}$ \\
\hline & $(0.005)$ & $(0.105)$ & $(0.009)$ & $(1.663)$ & $(0.086)$ \\
\hline \multirow[t]{2}{*}{ LR:EXCH } & $-0.003^{* * *}$ & 0.131 & $0.027^{* * *}$ & -0.414 & $0.054^{* *}$ \\
\hline & $(0.000)$ & $(0.145)$ & $(0.005)$ & (1.478) & $(0.010)$ \\
\hline \multirow[t]{2}{*}{ LR:STMCAP/GDP } & -0.010 & -9.961 & $-0.004^{\star}$ & 0.937 & $-0.056^{\star *}$ \\
\hline & $(0.006)$ & $(9.905)$ & $(0.002)$ & $(3.176)$ & $(0.011)$ \\
\hline \multirow[t]{2}{*}{ LR:M2/GDP } & 0.009 & 0.011 & $0.008^{* * *}$ & 0.235 & $-0.048^{\star *}$ \\
\hline & $(0.005)$ & $(0.013)$ & $(0.001)$ & $(1.145)$ & $(0.011)$ \\
\hline \multirow[t]{2}{*}{ SR:LD.lnGDP } & -0.099 & $-1.033^{* * *}$ & $-1.292^{\star *}$ & -0.029 & $1.240^{* * *}$ \\
\hline & $(0.060)$ & $(0.143)$ & $(0.316)$ & $(0.094)$ & $(0.084)$ \\
\hline \multirow[t]{2}{*}{ SR:D.Savings/GDP } & $0.003^{* * *}$ & -0.000 & $-0.006^{\star}$ & $0.008^{* *}$ & $0.019^{* * *}$ \\
\hline & $(0.000)$ & $(0.001)$ & $(0.002)$ & $(0.003)$ & $(0.001)$ \\
\hline \multirow[t]{2}{*}{ SR:LD.Savings/GDP } & & $0.002^{*}$ & $-0.014^{\star *}$ & $0.006^{* *}$ & \\
\hline & & $(0.001)$ & $(0.003)$ & $(0.002)$ & \\
\hline \multirow[t]{2}{*}{ SR:D.PSC/GDP } & $0.003^{* *}$ & $0.011^{* * *}$ & $0.028^{\star *}$ & $-0.009^{*}$ & $-0.001^{* *}$ \\
\hline & $(0.001)$ & $(0.002)$ & $(0.007)$ & $(0.003)$ & $(0.000)$ \\
\hline \multirow[t]{2}{*}{ SR:LD.PSC/GDP } & & $0.011^{* *}$ & -0.011 & $-0.011^{\star *}$ & $-0.003^{* * *}$ \\
\hline & & $(0.002)$ & $(0.005)$ & $(0.003)$ & $(0.000)$ \\
\hline \multirow[t]{2}{*}{ SR:D.INFLATION } & 0.001 & 0.000 & $0.040^{\star *}$ & & $-0.018^{\star * *}$ \\
\hline & $(0.001)$ & $(0.001)$ & $(0.009)$ & & $(0.001)$ \\
\hline \multirow[t]{2}{*}{ SR:LD.INFLATION } & $0.004^{* * *}$ & & -0.009 & & $-0.003^{* * *}$ \\
\hline & $(0.000)$ & & $(0.004)$ & & $(0.000)$ \\
\hline \multirow[t]{2}{*}{ SR:D.EXCH } & $-0.001^{* * *}$ & $-0.004^{\star *}$ & -0.006 & $0.003^{*}$ & $-0.011^{\star * *}$ \\
\hline & $(0.000)$ & $(0.001)$ & $(0.005)$ & $(0.001)$ & $(0.001)$ \\
\hline \multirow[t]{2}{*}{ SR:LD.EXCH } & $-0.000^{\star *}$ & $-0.003^{* *}$ & & $0.006^{* * *}$ & $-0.001^{\star *}$ \\
\hline & $(0.000)$ & $(0.001)$ & & $(0.001)$ & $(0.000)$ \\
\hline \multirow[t]{2}{*}{ SR:D.STMCAP/GDP } & $0.003^{* * *}$ & $0.432^{\star * *}$ & -0.003 & $-0.006^{* * *}$ & $0.002^{* * *}$ \\
\hline & $(0.000)$ & $(0.060)$ & $(0.002)$ & $(0.001)$ & $(0.000)$ \\
\hline SR:LD.STMCAP/GDP & -0.000 & $0.276^{\star *}$ & -0.001 & -0.001 & $0.001^{* * *}$ \\
\hline
\end{tabular}




\begin{tabular}{cccccc} 
Continued & \multicolumn{1}{c}{} & \\
\hline & $(0.000)$ & $(0.063)$ & $(0.001)$ & $(0.001)$ & $(0.000)$ \\
SR:D.M2/GDP & -0.002 & $-0.002^{*}$ & $0.008^{* *}$ & -0.004 & $0.001^{* *}$ \\
& $(0.001)$ & $(0.001)$ & $(0.002)$ & $(0.002)$ & $(0.000)$ \\
SR:LD.M2/GDP & -0.000 & & & $0.007^{* *}$ & $0.008^{* * *}$ \\
& $(0.001)$ & & & $(0.002)$ & $(0.000)$ \\
SR:_cons & $4.116^{* * *}$ & 1.507 & $-20.424^{* *}$ & 0.363 & $1.840^{* *}$ \\
& $(0.355)$ & $(1.282)$ & $(3.922)$ & $(0.795)$ & $(0.278)$ \\
Obs. & 22 & 22 & 22 & 22 & 22 \\
R-squared & 0.753 & 0.871 & 0.678 & 0.789 & 0.875 \\
\hline
\end{tabular}

Standard errors are in parenthesis, ${ }^{* *} \mathrm{p}<0.01,{ }^{* *} \mathrm{p}<0.05,{ }^{*} \mathrm{p}<0.1$.

Dumitrescu \& Hurlin (2012) Granger non-causality test results:

Lag order: 1.

$\mathrm{W}$-bar $=2.6811$.

Z-bar $=3.3622\left(\mathrm{p}\right.$-value ${ }^{*}=0.0250,95 \%$ critical value $\left.=2.7692\right)$.

Z-bar tilde $=2.5933$ ( $\mathrm{p}$-value ${ }^{\star}=0.0250,95 \%$ critical value $\left.=2.1035\right)$.

H0: STMCAP/GDP does not Granger-cause lnGDP.

H1: STMCAPGDP does Granger-cause lnGDP for at least one panelvar (ID).

${ }^{*} \mathrm{p}$-values computed using 1000 bootstrap replications.

We find bi-directional causality between stock market development (STMCAP/GDP) and economic growth (lnGDP).

The table below is the report of the regression results with lnGDP (economic growth as the dependent variable) for countries with conitegrated series.

As reported in Table 17, the long run coefficients of stock market development (STMCAP/GDP) are negative and statistically significant at $10 \%$ and $5 \%$ for Namibia and Mauritius respectively. The coefficient of financial development indicator (M2/GDP) is also positive and statistically significant at $1 \%$ in Namibia but negative and statistically significant at $5 \%$ in Mauritius.

Table 18 is the report of the regression results with lnGDP (economic growth) as the dependent variable for countries without conitegrated series.

We find that all the short run coefficients of the key variables of interest (STMCAP/GDP and M2/GDP) in the models are not statistically significant in Tunisia, South Africa and Eswatini. This finding is consistent with the findings of Nyasha and Odhiambo (2015) who established that market based financial development indicator was however statistically insignificant in South Africa.

The regression result for the paneljoint analysis is presented in Table 19. We found that all the long run coefficients of the explanatory variables are not statistically significant. However, the short run error correction is statistically significant at $5 \%$. The short run coefficients of savings to GDP ratio (Savings/GDP) and exchange rate (EXCH) are also statistically significant at $5 \%$ and $1 \%$ respectively. 
A. Michael et al.

Table 18. Regression results.

\begin{tabular}{|c|c|c|c|}
\hline & Tunisia & South Africa & Eswatini \\
\hline & $\operatorname{lnGDP}$ & $\operatorname{lnGDP}$ & $\operatorname{lnGDP}$ \\
\hline \multirow[t]{2}{*}{ L.lnGDP } & 0.392 & 0.609 & 1.183 \\
\hline & $(0.551)$ & $(0.397)$ & $(0.464)$ \\
\hline \multirow[t]{2}{*}{ L2.lnGDP } & 0.375 & 0.420 & 0.623 \\
\hline & $(0.618)$ & $(0.378)$ & $(0.423)$ \\
\hline \multirow[t]{2}{*}{ Savings/GDP } & 0.002 & -0.003 & 0.004 \\
\hline & $(0.005)$ & $(0.009)$ & $(0.002)$ \\
\hline \multirow[t]{2}{*}{ L.Savings/GDP } & $-0.013^{*}$ & -0.012 & 0.001 \\
\hline & $(0.005)$ & $(0.016)$ & $(0.002)$ \\
\hline \multirow[t]{2}{*}{ L2.Savings/GDP } & & & 0.007 \\
\hline & & & $(0.004)$ \\
\hline \multirow[t]{2}{*}{ PSC/GDP } & -0.002 & 0.001 & -0.025 \\
\hline & $(0.004)$ & $(0.001)$ & $(0.009)$ \\
\hline \multirow[t]{2}{*}{ L.PSC/GDP } & -0.004 & 0.002 & -0.017 \\
\hline & $(0.005)$ & $(0.001)$ & $(0.006)$ \\
\hline \multirow[t]{2}{*}{ L2.PSC/GDP } & & 0.003 & 0.004 \\
\hline & & $(0.004)$ & $(0.005)$ \\
\hline \multirow[t]{2}{*}{ INFLATION } & 0.017 & -0.002 & -0.001 \\
\hline & $(0.013)$ & $(0.005)$ & $(0.004)$ \\
\hline \multirow[t]{2}{*}{ L.INFLATION } & 0.008 & -0.005 & $-0.005^{*}$ \\
\hline & $(0.010)$ & $(0.002)$ & $(0.002)$ \\
\hline \multirow[t]{2}{*}{ L2.INFLATION } & & -0.000 & -0.006 \\
\hline & & $(0.003)$ & $(0.004)$ \\
\hline \multirow[t]{2}{*}{$\mathrm{EXCH}$} & -0.016 & -0.016 & $-0.027^{*}$ \\
\hline & $(0.062)$ & $(0.008)$ & $(0.007)$ \\
\hline \multirow[t]{2}{*}{ L.EXCH } & -0.049 & 0.001 & -0.013 \\
\hline & $(0.072)$ & $(0.019)$ & $(0.017)$ \\
\hline \multirow[t]{2}{*}{ L2.EXCH } & -0.044 & 0.015 & -0.007 \\
\hline & $(0.046)$ & $(0.019)$ & $(0.007)$ \\
\hline \multirow[t]{2}{*}{ STMCAP/GDP } & -0.001 & -0.000 & 0.003 \\
\hline & $(0.004)$ & $(0.000)$ & $(0.001)$ \\
\hline \multirow[t]{2}{*}{ L.STMCAP/GDP } & 0.002 & -0.000 & 0.001 \\
\hline & $(0.003)$ & $(0.000)$ & $(0.002)$ \\
\hline
\end{tabular}




\section{Continued}

\begin{tabular}{cccc}
\hline L2.STMCAP/GDP & -0.003 & -0.000 & \\
& $(0.002)$ & $(0.000)$ & \\
M2/GDP & 0.006 & -0.002 & 0.012 \\
& $(0.004)$ & $(0.002)$ & $(0.007)$ \\
L.M2/GDP & 0.001 & 0.003 & 0.006 \\
& $(0.003)$ & $(0.003)$ & $(0.010)$ \\
L2.M2/GDP & 0.000 & -0.005 & -0.004 \\
& $(0.003)$ & $(0.004)$ & $(0.005)$ \\
cons & 6.151 & -0.794 & $-18.745^{\star}$ \\
& $(4.190)$ & $(3.242)$ & $(5.372)$ \\
Obs. & 22 & 22 & 22 \\
R-squared & 0.677 & 0.567 & 0.697 \\
\hline
\end{tabular}

Standard errors are in parenthesis, ${ }^{* * *} \mathrm{p}<0.01,{ }^{* *} \mathrm{p}<0.05,{ }^{*} \mathrm{p}<0.1$.

Table 19. Regression results.

(1)

\begin{tabular}{|c|c|}
\hline & D.lnGDP \\
\hline Savings/GDP & $\begin{array}{l}-0.099 \\
(0.111)\end{array}$ \\
\hline $\mathrm{PSC} / \mathrm{GDP}$ & $\begin{array}{c}-0.049 \mathrm{~s} \\
(0.056)\end{array}$ \\
\hline INFLATION & $\begin{array}{c}0.303 \\
(0.337)\end{array}$ \\
\hline $\mathrm{EXCH}$ & $\begin{array}{c}0.228 \\
(0.213)\end{array}$ \\
\hline STMCAP/GDP & $\begin{array}{c}0.002 \\
(0.004)\end{array}$ \\
\hline M2GDP & $\begin{array}{c}0.077 \\
(0.071)\end{array}$ \\
\hline SR:_ec & $\begin{array}{l}0.006^{* *} \\
(0.003)\end{array}$ \\
\hline SR:D.Savings/GDP & $\begin{array}{l}0.002^{\star \star} \\
(0.001)\end{array}$ \\
\hline SR:D.PSC/GDP & $\begin{array}{c}0.000 \\
(0.001)\end{array}$ \\
\hline
\end{tabular}




\section{Continued}

\begin{tabular}{cc}
\hline SR:D.INFLATION & 0.000 \\
SR:D.EXCH & $(0.001)$ \\
SR:D.STMCAP/GDP & $-0.002^{\star * *}$ \\
& $(0.001)$ \\
SR:D.M2/GDP & -0.000 \\
SR:_cons & $(0.001)$ \\
& -0.001 \\
Obs. & $(0.001)$ \\
& -0.112 \\
\hline
\end{tabular}

Standard errors are in parenthesis, ${ }^{* * *} \mathrm{p}<0.01,{ }^{* *} \mathrm{p}<0.05,{ }^{*} \mathrm{p}<0.1$.

\section{Conclusion}

This study employed autoregressive distributed lag bounds test, co-integration test and granger causality test to examine the long-run and short run interrelationship among financial deepening, stock market development and economic growth in eight (8) Africa countries using annual data from the period 1996 to 2109. We showed from the granger causality test that stock market development only causes economic growth in Algeria, Namibia and Mauritius whilst a unidirectional causality from economic growth to stock market development was found in Kenya, Nigeria, Tunisia, Eswatini and South Africa. We also showed that the presence of co-integration among the series in five (5) countries (Nigeria, Algeria, Namibia, Kenya and Mauritius) and also for the entire panel.

Our results from the bounds test of the ARDL panel regression provided evidence of a positive relationship between stock market development and financial deepening in Africa. We also found the relationship between economic growth (lnGDP) and financial deepening (M2/GDP) to be negative in Africa. This means that with higher growth in the economy, corresponding growth in M2 must be attained to achieve higher growth in financial development. The time series result of the ARDL also provides mixed results for the effects of stock market development (STMCAP/GDP) on economic growth (lnGDP) in terms of statistical significance and direction (sign). For countries with the long run co-integrated series, we found that economic growth (lnGDP) positively and significantly affects financial deepening (M2/GDP) in Tunisia and South Africa but negatively in Eswatini. The stock market development indicator (STMCAP/GDP) also negatively and significantly affects financial deepening (M2/GDP) in Tunisia, South Africa and Eswatini.

We also presented further analysis among the development indicators using economic growth (lnGDP) as the dependent variable and financial deepening 
(M2/GDP) and stock market development as explanatory variables. We found the series to be co-integrated in five (5) countries (Nigeria, Algeria, Namibia, Kenya and Mauritius). From the long-run analysis, the study recorded positive and significant relationship between stock market development (STMCAP/GDP) only in Namibia and Mauritius. We also found that the relationship between financial deepening (M2/GDP) and economic growth (lnGDP) is positive in Namibia but negative in Mauritius. The short run analysis has also provided mixed evidence among the countries. Our findings from the granger causality test are consistent with the results of Pradhan (2018) who found both unidirectional and bi-directional causality between stock market development and economic growth per capita among G-20 economies from 1980 to 2015. In addition, our study shares similarities with Ake (2010) who employed times series data from the first quarter of 1995 to the fourth quarter of 2008 obtained from five (5) Euronext countries (Belgium, France, Portugal, Netherlands and United Kingdom) and established that countries with highly active and liquid stock markets the study found positive causal relationship between stock market and economic growth whereas no causal relationship was recorded in countries with less active and illiquid small stock markets.

Based on the results and discussions above, it is evident that the impact of the stock markets across Africa presents mixed results. We find that because most of the stock markets are small, less liquid and less efficient. We recommend and encourage financial markets players to institute major reforms and innovations in their stock markets to smooth out all the complexities and the inefficiencies inherent in their financial markets to achieve a positive link to the real side of the economy.

\section{Suggestion for Further Study}

It is suggested for further study that a comparative analysis is conducted between developed economies and developing economies as those in Africa, since this study only focuses on the interrelationships between financial development, stock market development and economic growth in Africa. Such a study will clearly provide evidence and the dynamics of the interrelationships between financial development, stock market development and growth for emerging economies to learn. Again, future studies may also analyse the effect of banking sector development on economic growth in Africa.

\section{Conflicts of Interest}

The authors declare no conflicts of interest regarding the publication of this paper.

\section{References}

Ake, B. (2010). The Role of Stock Market Development in Economic Growth: Evidence from Some Euronext Countries. International Journal of Financial Research, 1, 14-20. 
https://doi.org/10.5430/ijfr.v1n1p14

https://ssrn.com/abstract=2012518

Arestis, P., Demetriades, P., \& Luintel, K. (2001). Financial Development and Economic Growth: The Role of Stock Markets. Journal of Money, Credit and Banking, 33, 16-41. https://doi.org/10.2307/2673870

Azarmi, T., Lazar, D., \& Jeyapaul, J. (2005). Is The Indian Stock Market A Casino? Journal of Business \& Economics Research, 3, 63-72. https://doi.org/10.19030/jber.v3i4.2767

Capasso, S. (2008). Stock Market Development and Economic Growth. In G. Mavrotas (Ed.), Domestic Resource Mobilization and Financial Development (pp. 10-38). London: Palgrave Macmillan. https://doi.org/10.1057/9780230594012_2

Dumitrescu, E.-I., \& Hurlin, C. (2012). Testing for Granger Non-Causality in Heterogeneous Panels. Economic Modelling, 29, 1450-1460. https://doi.org/10.1016/j.econmod.2012.02.014

Francis, B. B., \& Ofori, E. (2015). Political Regimes and Stock Market Development. Eurasian Economic Review, 5, 111-137. https://doi.org/10.1007/s40822-015-0018-5

Guglielmo, M. C, \& Howells, P. G. A., \& Soliman, A. M. (2004). Stock Market Development and Economic Growth: The Causal Linkage. Journal of Economic Development, Chung-Ang Unviersity, Department of Economics, 29, 33-50.

Handal, A. H. (2013). Causality Relationship between Macroeconomic Variables and Stock Market Development: Evidence from Bahrain. The International Journal of Business and Finance Research, 7, 769-784. https://ssrn.com/abstract=2148672

Hou, H., \& Cheng, S. Y. (2010). The Roles of Stock Market in the Finance-Growth Nexus: Time Series Cointegration and Causality Evidence from Taiwan. Applied Financial Economics, 20, 975-981. https://doi.org/10.1080/09603101003724331

Jahfer, A., \& Inoue, T. (2014). Financial Development and Economic Growth: The Role of Stock Market in Japan. International Review of Business Research Papers, 10, 46-61. http://dx.doi.org/10.21102/irbrp.2014.09.102.04

Matadeen, J., \& Seetanah, B. (2015). Stock Market Development and Economic Growth: Evidence from Mauritius. The Journal of Developing Areas, 49, 25-36. https://doi.org/10.1353/jda.2015.0120

Modigliani, F., \& Miller, M. (1958). The Cost of Capital, Corporation Finance and the Theory of Investment. The American Economic Review, 48, 261-297. http://www.jstor.org/stable/1809766

Nagaishi, M. (1999). Stock Market Development and Economic Growth: Dubious Relationship. Economic and Political Weekly, 34, 2004-2012. http://www.jstor.org/stable/4408209

Nyasha, S., \& Odhiambo, N. M. (2015). The Impact of Banks and Stock Market Development on Economic Growth in South Africa: An ARDL-Bounds Testing Approach. Contemporary Economics, 9, 93-108. https://ssrn.com/abstract=2607432

Okoye, L. U., Modebe, N. J., Taiwo, J. N., \& Okorie, U. E. (2016). Impact of Capital Market Development on the Growth of the Nigerian Economy. Research Journal of Financial Sustainability Reporting, 1, 24-32.

Pesaran, M. H., Shin, Y., \& Smith, R. J. (2001). Bounds Testing Approaches to the Analysis of Long Run Relationships. Journal of Applied Econometrics, 16, 289-326. https://doi.org/10.1002/jae.616

Pinto, P. M., Weymouth, S., \& Gourevitch, P. (2010). The Politics of Stock Market De- 
velopment. Review of International Political Economy, 17, 378-409.

https://doi.org/10.1080/09692290903310424

Pradhan, R. P. (2011). Financial Development, Growth and Stock Market Development: The Trilateral Analysis in India. Journal of Quantitative Economics, the Indian Econometric Society, 9, 134-145.

Pradhan, R. P. (2018). Development of Stock Market and Economic Growth: The G-20 Evidence. Eurasian Economic Review, 8, 161-181.

https://doi.org/10.1007/s40822-018-0094-4

Taiwo, J. N., Alaka, A., \& Afieroho, E. O. (2016). Capital Market and Economic Growth in Nigeria. Account and Financial Management Journal, 1, 497-525.

Toda, H. Y., \& Yamamoto, T. (1995). Statistical Inference in Vector Autoregressions with Possibly Integrated Processes. Journal of Econometrics, 66, 225-250. https://doi.org/10.1016/0304-4076(94)01616-8

Udegbunam, R. (2002). Openness, Stock Market Development, and Industrial Growth in Nigeria. The Pakistan Development Review, 41, 69-92.

https://doi.org/10.30541/v41i1pp.69-92 http://www.jstor.org/stable/41260413

Vo, X. V., Nguyen, H. H., \& Pham, K. D. (2016). Financial Structure and Economic Growth: The Case of Vietnam. Eurasian Business Review, 6, 141-154. https://doi.org/10.1007/s40821-016-0042-8

Yu, J. S., Kabir Hassan, M., \& Sanchez, B. (2012). A Re-Examination of Financial Development, Stock Markets Development and Economic Growth. Applied Economics, 44, 3479-3489. https://doi.org/10.1080/00036846.2011.577019 